\title{
Influence of intracoronary nifedipine on left ventricular function, coronary vasomotility, and myocardial oxygen consumption
}

\author{
PATRICK W SERRUYS, TON E H HOOGHOUDT, JOHAN H C REIBER, CORNELIS \\ SLAGER, RONALD W BROWER, PAUL G HUGENHOLTZ
}

From Thoraxcenter, Erasmus University, Rotterdam, The Netherlands

SUMMARY The effect of intracoronary nifedipine on regional and global left ventricular performance, coronary vasomotility, and myocardial oxygen consumption is reported. Left ventricular pressures and volume indices of contractility and relaxation were simultaneously recorded in five patients without coronary artery disease. In these patients, nifedipine in the left main coronary artery not only delayed ( $+115 \mathrm{~ms}$ ) anterior wall contraction but also slowed $(3.5 \mathrm{vs} 1.9 \mathrm{~cm} / \mathrm{s})$ and depressed it $(-26 \%)$, resulting in a depression of global left ventricular ejection. This asynchrony and depression of regional contraction is considered to be responsible for the slowed isovolumic contraction and relaxation of the whole ventricle. In 10 other patients with coronary artery disease, coronary sinus blood flow and myocardial oxygen consumption were measured before and after intracoronary nifedipine. The observed decrease in myocardial oxygen consumption ( $-28 \%)$ depended primarily on a decrease in contractility and left ventricular performance. In a third study group of 12 patients with coronary artery disease, the effects of intracoronary nifedipine on the coronary vasomotility of $\mathbf{4 0}$ coronary segments (normal, prestenotic, stenotic, poststenotic) were quantitatively determined. Left ventricular haemodynamics and coronary sinus saturation were monitored while the cineangiograms were recorded before and after nifedipine. Nifedipine provoked vasodilatation of the normal $(+10 \cdot 3 \%)$, prestenotic, stenotic $(+4$ to $30 \%)$, and poststenotic $(+16.4 \%)$ coronary segments, which persisted after the disappearance of its direct effects on the myocardium. This transient regional "cardioplegic" effect of nifedipine, associated with an increase in coronary blood flow, a reduction in myocardial oxygen consumption, and a vasodilatation of the epicardial vessels is likely to be beneficial during temporary coronary occlusion such as occurs in spasm or transluminal angioplasty.

Direct intracoronary injection of nifedipine is used increasingly in an effort to reverse spontaneously occurring or induced spasm 12 and to restore coronary blood flow. Recently introduced techniques, such as transluminal angioplasty and fibrinolytic recanalisation of coronary artery thrombosis have also become indications ${ }^{34}$ for injecting nifedipine directly into the affected coronary artery, since it is argued that the specific inhibitory action of nifedipine on contractile energy expenditure may favourably influence the

Part of this work has been presented at the 53rd and 54th Scientific Sessions of the American Heart Association.

Accepted for publication 9 November 1982 oxygen supply/demand ratio for ischaemic or potentially ischaemic cardiac cells in the affected region.

Because of the potential value of this drug, it is necessary to determine to what extent selective intracoronary bolus injection depresses left ventricular performance in man and/or reduces the myocardial oxygen consumption while at the same time dilating the coronary artery system.

\section{Patients and methods}

PATIENT AND DESIGN OF STUDY

For the first part of the study, five patients ( 32 to $5 j$ years) were catheterised because of suspected coronary artery disease. Four had atypical chest pain and 
one had exertional angina, but all proved to have normal coronary arteries, with ejection fractions well within the normal range. One patient, however, had asymmetrical septal hypertrophy without outflow obstruction and one had electrocardiographic evidence of left ventricular hypertrophy without strain.

Pressures were recorded with a tip-manometer mounted on an $8 \mathrm{~F}$ catheter ${ }^{\star}$. Derived variables were calculated on line by a computer system..$^{5} \mathrm{~A} 30^{\circ}$ right anterior oblique ventriculogram (50 frames per second) was obtained by injection of $0.75 \mathrm{ml} / \mathrm{kg} 76 \%$ Urografint. When diagnostic coronary arteriography showed normal coronary arteries, informed consent was obtained for the remainder of the study. This included an additional left ventricular cineangiogram 30 seconds after a bolus injection of 0.075 to $0.175 \mathrm{mg}$ nifedipine into the left main coronary artery. The injection was made no sooner than 20 minutes and only after left ventricular end-diastolic pressure and the contractility variables were identical with those recorded before the initial angiogram.

The patient's position was kept unchanged in relation to the $x$-ray equipment during both angiograms. Movement of the diaphragm was excluded by shallow inspiration, taking care to prevent the Valsalva manoeuvre.

\section{ANALYSIS OF ISOVOLUMIC INDICES DURING VENTRICULOGRAPHY}

The on-line computer system provides the following data: peak left ventricular pressure $(\mathrm{mmHg})$, left ventricular end-diastolic pressure $(\mathrm{mmHg})$, and peak positive rate of change of pressure $(\mathrm{pk}+\mathrm{dP} / \mathrm{dt}$ in $\mathrm{mmHg} / \mathrm{s}$ ). In addition, isovolumic relaxation phase variables were calculated: peak negative rate of change of pressure (pk-dP/dt) and the time constant of relaxation ( $T$ ) by the least squares fit of $P=e^{A t+B}$ $(T=-1 / A)$ from the moment of $\mathrm{pk}-\mathrm{dP} / \mathrm{dt}$ to the opening of the mitral valve. ${ }^{6}$ The opening of the mitral valve was defined from the angiographic frame preceding that in which non-opacified blood first entered the left ventricle. In all cases mitral valve opening was identified in the same frame by two independent observers. ${ }^{6}$

\section{ANALYSIS OF GLOBAL AND REGIONAL LEFT VENTRICULAR FUNCTION DURING SYSTOLE AND DIASTOLE}

From all cineangiograms one complete cardiac cycle was analysed frame by frame. Films were projected with a $35 \mathrm{~mm}$ film projector and converted into video format with a video camerał. The ventricular contour was detected automatically with a dedicated hard

* Millar Instruments Inc, Houston, Texas, USA.

† Schering AG, Berlin, Bergkammen, GFR.

$¥$ Philips, Eindhoven, The Netherlands. wired system. ${ }^{7}$ Left ventricular volume was computed according to Simpson's rule for each frame. Stroke volume, global ejection fraction, and total cardiac index were determined. End-diastole was defined as the moment when the derivative of left ventricular pressure first exceeded $200 \mathrm{mmHg} / \mathrm{s}$. In all cases this point coincided with the maximal measured volume. End-systole was defined at the occurrence of the incisura of the central aortic pressure, recorded with a tip-manometer on a $5 \mathrm{~F}$ catheter ${ }^{\star}$. Early diastole was defined as the interval between the opening of the mitral valve and minimal ventricular diastolic pressure. Early diastolic left ventricular inflow volume was measured as an absolute value (ml), and early diastolic mean inflow rate was calculated as the ratio between the difference of ventricular volumes at minimal pressure and opening of the mitral valve and the time interval corresponding to the number of frames between them.

To analyse regional left ventricular function, a system of 20 co-ordinates is generated ${ }^{7}$ along which the left ventricular displacement is determined frame by frame (Fig. 1).

The orientation of the 20 co-ordinate axes was originally developed from the motion of these endocardial sites in normal subjects ${ }^{7}$ and formulated in a generalised mathematical expression amenable to automatic data processing.

Regional wall velocity was computed as the first derivative of the instantaneous displacement function. Mean wall velocity $\overline{(\bar{V})}$ was calculated from enddiastole to end-systole (Fig. 1).

To express quantitatively the contribution of a particular segment to global ejection fraction, segmental volume was computed from the local radius and the height of each segment and indexed for end-diastolic volume (Fig. 2). This was termed regional contribution to global ejection fraction. The sum of all 20 determinations equals the global ejection fraction. Diastolic pressure-volume relations were determined from the minimal diastolic pressure to the beginning of the " $a$ " wave. The natural logarithm of pressure was used in a linear regression analysis of pressure and volume from which a slope $k$ was derived. Changes in $\mathrm{k}$ were taken as changes in volume stiffness. ${ }^{8}$

\section{CORONARY SINUS BLOOD FLOW MEASUREMENT} AND MYOCARDIAL OXYGEN CONSUMPTION In the second part of this study, the effect of intracoronary injection of nifedipine on coronary sinus blood flow and myocardial oxygen consumption was determined in 10 other patients (54 to 68 years), who all had significant coronary heart disease.

Blood flow was measured via the continuous ther-

^Millar Instruments Inc, Houston, Texas, USA. 


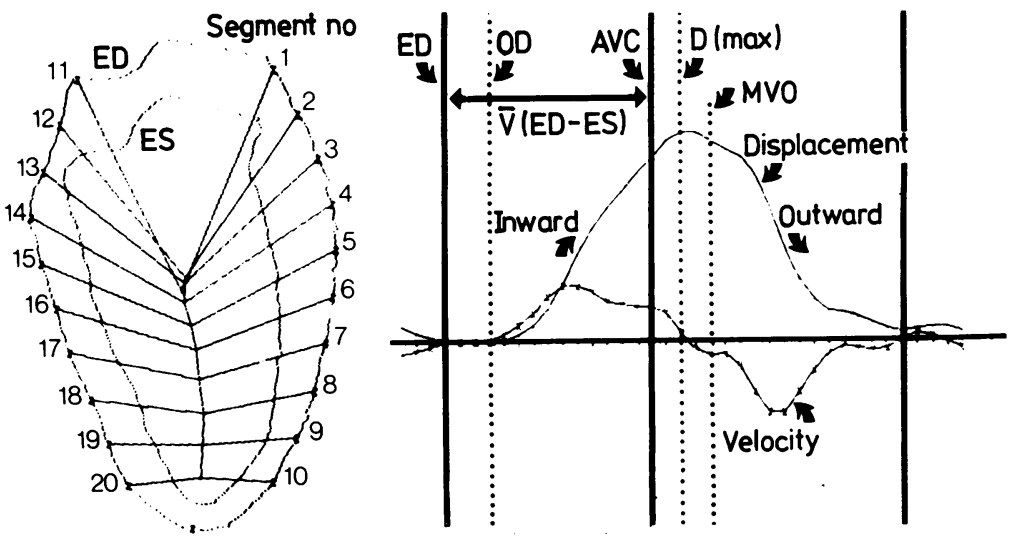

Fig. 1 End-diastolic and end-systolic left ventricular contours, as detected with the automated analysis system. On these silhouettes is superimposed a system of co-ordinates along which segmental left ventricular wall displacement is detected. Left ventricular wall velocity first derivative of wall displacement -is derived from these data. $E D$, end-diastole; $E S$, end-systole; $O D$, onset of displacement; $\bar{V}(E D-E S)$, mean systolic wall velocity; $D$ (max), maximal inward wall displacement; MVO, mitral valve opening; $A V C$, aortic valve closure.

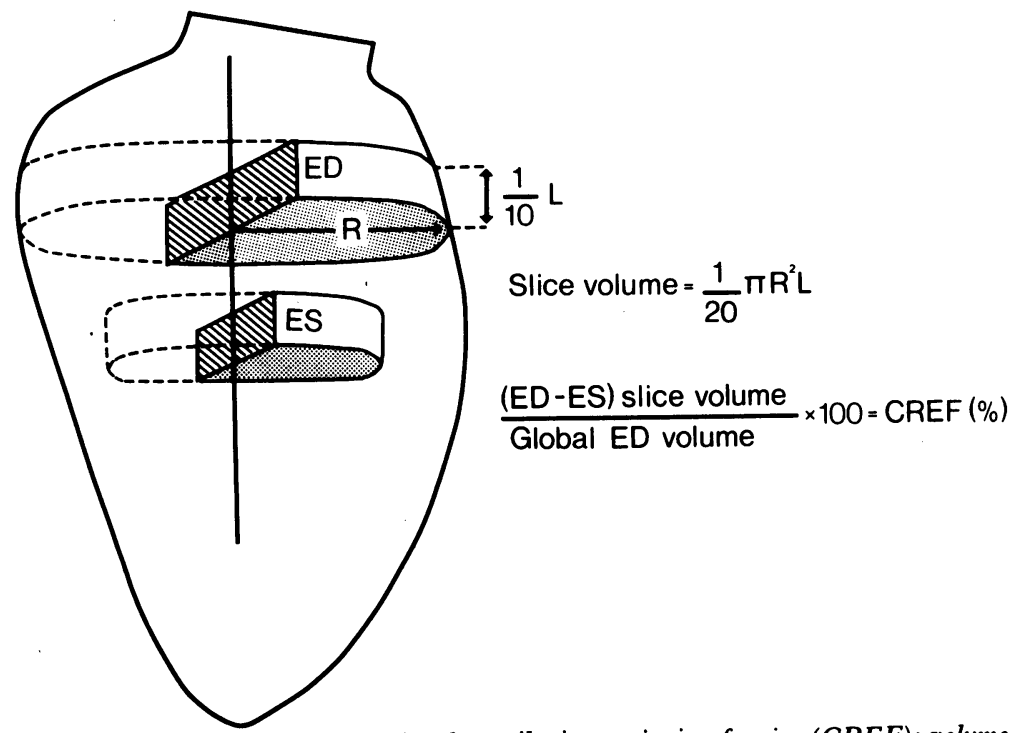

Fig. 2 Method for computing regional contribution to ejection fraction (CREF): volume of each segment (slice volume) is computed according to the formula, shown in the Figure. The systolic volume change is normalised for left ventricular end-diastolic volume.

modilution method of Ganz et al. ${ }^{9}$ The position of the external thermistor was assessed by injection of $3 \mathrm{ml}$ contrast material before the intracoronary injection of $0.1 \mathrm{mg}$ nifedipine.

Before injecting nifedipine, the blood oxygen content in the aorta and in the coronary sinus was determined ${ }^{\star}$ and baseline data for flow and aortic pressures

\footnotetext{
${ }^{\star}$ Lex-O- ${ }_{2}-\mathrm{CON}$, Lexington Instruments Corporation, Waltham, Mass., USA.
}

were obtained during 60 seconds. Thirty seconds and three minutes after the intracoronary administration of nifedipine these measurements were repeated and changes in myocardial oxygen consumption computed.

QUANTITATIVE CORONARY ANGIOGRAPHY

For the third part of the study, coronary artery dimensions were quantified in 12 patients ( 33 to 59 
years), again catheterised for suspected coronary artery disease. Two patients had completely normal coronary arteries, one had single vessel disease, six had double vessel disease, and three had triple vessel disease, all with obstruction of $70 \%$ or more. The effects of intracoronary injection of nifedipine on coronary vasomotility were studied in four consecutive coronary cineangiograms. Before the angiographic study, a fibreoptic catheter was inserted into the coronary sinus and the $\mathrm{O}_{2}$ saturation was continuously measured. ${ }^{10}$ The left ventricular pressure was also recorded continuously with a dual tip-manometer and analysed for changes in left ventricular contractility, reflected by peak $\mathrm{dP} / \mathrm{dt}$, peak VCE, and $\mathrm{V}_{\max }{ }^{5} \mathrm{~A}$ total of $\mathbf{4 0}$ coronary segments was selected for quantitative angiographic analysis. Eight were stenotic in nature, five were prestenotic, 17 were poststenotic, and 10 were normal. Before injecting the nifedipine, two baseline coronary angiograms $(\mathrm{Cl}, \mathrm{C} 2)$ were performed five minutes apart. The second control angiogram (C2) was carried out to study the effect of the contrast agent itself on the artery. Five minutes later, $0.15 \mathrm{mg}$ nifedipine was injected within $20 \mathrm{sec}-$ onds into the left main coronary artery.

A third arteriogram (N1) was then obtained as soon as the coronary sinus saturation reached its maximum value, usually within 30 seconds. The final coronary angiogram (N2) was recorded when the coronary sinus saturation had returned to its control values, usually within five minutes. All arteriograms were obtained via the Sones technique and recorded on Kodak $35 \mathrm{~mm}$ cinefilm at the rate of 50 frames per second with the biplane Cardioskope $U^{\star}$. The contrast medium, $76 \%$ Urografin, was injected at a flow rate of $3 \mathrm{ml} / \mathrm{s}$ with a Medrad injector. To analyse a coronary segment, the $35 \mathrm{~mm}$ cinefilm is mounted on a

^Siemens AG, Henkesstrasse, Erlangen, GBR.

Fig. 3 Cineangiogram of the left anterior descending coronary artery in the right anterior oblique projection. The detected contours are superimposed on the original video image. Administrative data are displayed at the top. The diameter function along this coronary segment is also displayed on the video screen. 
Table la Left ventricular volume measurements and derived indices

\begin{tabular}{|c|c|c|c|c|c|c|c|c|c|c|c|}
\hline \multirow[t]{2}{*}{$\begin{array}{l}\text { Case } \\
\text { No. }\end{array}$} & \multirow[t]{2}{*}{$\begin{array}{l}\text { Dose IC } \\
\text { nifedipine (mg) }\end{array}$} & \multicolumn{2}{|c|}{$\begin{array}{l}\text { Heart } \\
\text { ratelmin }\end{array}$} & \multicolumn{2}{|c|}{$\begin{array}{l}\text { EDVI } \\
\left(\mathrm{ml} / \mathrm{m}^{2}\right)\end{array}$} & \multicolumn{2}{|c|}{$\begin{array}{l}E S V I \\
\left(m l / m^{2}\right)\end{array}$} & \multicolumn{2}{|l|}{$\begin{array}{l}S I \\
\left(\mathrm{mllm}^{2}\right)\end{array}$} & \multicolumn{2}{|l|}{$\begin{array}{l}E F \\
(\%)\end{array}$} \\
\hline & & $C$ & $N$ & $C$ & $N$ & $C$ & $N$ & $C$ & $N$ & $C$ & $N$ \\
\hline \multirow[t]{2}{*}{$\begin{array}{l}1 \\
2 \\
3 \\
4 \\
5\end{array}$} & $\begin{array}{l}0.075 \\
0.15 \\
0.175 \\
0.125 \\
0.1\end{array}$ & $\begin{array}{l}75 \\
67 \\
66 \\
70 \\
66\end{array}$ & $\begin{array}{l}74 \\
72 \\
66 \\
86 \\
71\end{array}$ & $\begin{array}{c}75.1 \\
92 \\
80.4 \\
122.6 \\
69.2\end{array}$ & $\begin{array}{r}79.1 \\
89.1 \\
88.4 \\
101.5 \\
60.6\end{array}$ & $\begin{array}{l}21.4 \\
26.4 \\
27.3 \\
34.4 \\
11.7\end{array}$ & $\begin{array}{l}29.9 \\
43.6 \\
47.2 \\
51.5 \\
26.1\end{array}$ & $\begin{array}{l}53.6 \\
65.6 \\
53.1 \\
88.1 \\
57.5\end{array}$ & $\begin{array}{l}49.2 \\
45.5 \\
41 \cdot 1 \\
50 \\
34.4\end{array}$ & $\begin{array}{l}71.4 \\
71.3 \\
65.9 \\
71.9 \\
83\end{array}$ & $\begin{array}{l}62.1 \\
51 \\
46.5 \\
49.2 \\
56.8\end{array}$ \\
\hline & $\begin{array}{l}\text { Mean } \\
\text { SD } \\
\mathrm{p} \text { value }\end{array}$ & $\begin{array}{r}69 \\
\pm 4\end{array}$ & $\begin{array}{r}74 \\
\pm 7\end{array}$ & $\begin{array}{r}88 \\
\pm 21\end{array}$ & $\begin{array}{r}84 \\
\pm 15\end{array}$ & $\begin{array}{r}24 \\
\pm 8\end{array}$ & $\begin{array}{r}40 \\
\pm 11 \\
002\end{array}$ & $\begin{array}{r}64 \\
\pm 15\end{array}$ & $03^{ \pm 6}$ & $\begin{array}{r}73 \\
\pm 6\end{array}$ & $\begin{array}{r}53 \\
\pm 6 \\
005\end{array}$ \\
\hline
\end{tabular}

IC, intracoronary EDVI, end-diastolic volume index; ESVI, end-systolic volume index; SI, stroke index; EF, ejection fraction; C, control; N, nifedipine.

Table lb Left ventricular pressure measurements and derived indices

\begin{tabular}{|c|c|c|c|c|c|c|c|c|c|c|}
\hline \multirow{2}{*}{$\begin{array}{l}\text { Case } \\
\text { No. }\end{array}$} & \multicolumn{2}{|c|}{$P_{\min }(m m H g)$} & \multicolumn{2}{|l|}{$k_{p} / m l$} & \multicolumn{2}{|c|}{$E D P(m m H g)$} & \multicolumn{2}{|c|}{$\operatorname{peak}(+) d P / d t(m m H g / s)$} & \multicolumn{2}{|c|}{ peak VCE/s } \\
\hline & $C$ & $N$ & $C$ & $N$ & $C$ & $N$ & $C$ & $N$ & $C$ & $N$ \\
\hline 1 & 0.3 & $6 \cdot 5$ & $\begin{array}{l}0.125 \\
r=0.88\end{array}$ & $\begin{array}{l}0.045 \\
r=0.96\end{array}$ & $8 \cdot 7$ & $17 \cdot 4$ & 1830 & 1460 & 47 & 39 \\
\hline 2 & 6 & $13 \cdot 1$ & $\begin{array}{l}0.029 \\
r=0.97\end{array}$ & $\begin{array}{l}0.007 \\
r=0.72\end{array}$ & $20 \cdot 8$ & 23 & 1440 & 1110 & 29 & 24 \\
\hline 3 & 1.4 & 14 & $\begin{array}{l}0.048 \\
r=0.97\end{array}$ & $\begin{array}{l}0.012 \\
r=0.97\end{array}$ & 9.9 & 21 & 1410 & 1020 & 36 & 20 \\
\hline 4 & 0 & 13 & $\begin{array}{l}0.061 \\
r=0.96\end{array}$ & $\begin{array}{l}0.03 i \\
r=0.97\end{array}$ & $12 \cdot 1$ & $22 \cdot 8$ & 1470 & 1130 & 38 & 25 \\
\hline 5 & 0.3 & $8 \cdot 1$ & $\begin{array}{l}0.158 \\
r=0.89\end{array}$ & $\begin{array}{l}0.049 \\
r=0.98\end{array}$ & 10.4 & $21 \cdot 6$ & 1730 & 1020 & .54 & 22 \\
\hline $\begin{array}{l}\text { Mean } \\
\text { SD } \\
\mathrm{p} \text { value }\end{array}$ & $\begin{array}{r}1.6 \\
\pm 2.5\end{array}$ & $\begin{array}{r}11 \\
\pm 3 \\
<0.005\end{array}$ & $\begin{array}{r}0.084 \\
\pm 0.054\end{array}$ & $\begin{array}{r}0.029 \\
\pm 0.019 \\
<0.03\end{array}$ & $\begin{array}{r}12 \\
\pm 5\end{array}$ & $\begin{array}{r}21 \\
\pm 2 \\
0.01\end{array}$ & $\begin{aligned} & 1576 \\
\pm & 191\end{aligned}$ & $<_{<0.005} \pm^{1148}$ & $\begin{array}{l}41 \\
\pm 10 \\
<0.05\end{array}$ & $\begin{array}{r}26 \\
\pm \quad 8\end{array}$ \\
\hline
\end{tabular}

$P_{\min }$, left ventricular minimal diastolic pressure; $k_{n}$, slope of diastolic logarithmic pressure volume relation; EDP, end-diastolic pressure; $\mathrm{dP} / \mathrm{dt}$, rate of change of pressure. Values expressed as means $\pm \mathrm{SD}$.

\begin{tabular}{|c|c|c|c|c|c|c|c|c|c|c|c|c|}
\hline \multirow[t]{2}{*}{$\begin{array}{l}\text { Case } \\
\text { No. }\end{array}$} & \multicolumn{2}{|l|}{$V_{\max } / s$} & \multicolumn{2}{|c|}{$\begin{array}{l}\text { Peak LVP } \\
(\mathrm{mmHg})\end{array}$} & \multicolumn{2}{|c|}{$E S P(m m H g)$} & \multicolumn{2}{|c|}{$T S R$ dyne $\mathrm{sm}^{-5}$} & \multicolumn{2}{|c|}{$\begin{array}{l}\text { Peak }(-) d P / d t \\
(m m H g / s)\end{array}$} & \multicolumn{2}{|c|}{$T C R(m s)$} \\
\hline & $C$ & $N$ & $C$ & $N$ & $C$ & $N$ & $C$ & $N$ & $C$ & $N$ & $C$ & $N$ \\
\hline 1 & 59 & 50 & 138 & 132 & 71 & 70 & 1054 & 1137 & 2081 & 1454 & 35.4 & $60 \cdot 8$ \\
\hline 2 & 41 & 31 & 98 & 91 & 79 & 59 & 879 & 962 & 1367 & 1073 & 51.5 & $70 \cdot 3$ \\
\hline 3 & 41 & 26 & 101 & 95 & 81 & 59 & 1114 & 1180 & 1792 & 825 & $35 \cdot 1$ & $84 \cdot 2$ \\
\hline 4 & 48 & 30 & 120 & 113 & 94 & 82 & 763 & 974 & 1520 & 1248 & $43 \cdot 2$ & $68 \cdot 2$ \\
\hline 5 & 58 & 34 & 135 & 91 & 102 & 58 & 1364 & 1233 & 2164 & 1310 & $21 \cdot 0$ & $47 \cdot 5$ \\
\hline $\begin{array}{l}\text { Mean } \\
\text { SD } \\
p \text { value }\end{array}$ & $\begin{array}{r}50 \\
\pm 9\end{array}$ & $\begin{array}{c}34 \\
\pm 9 \\
005\end{array}$ & $\begin{aligned} & 118 \\
\pm & 19\end{aligned}$ & $\mathrm{NS}^{ \pm 18}$ & $\begin{array}{r}86 \\
\pm 12\end{array}$ & $\begin{array}{r}66 \\
\pm 10 \\
0.05\end{array}$ & $1035=$ & NS & $\begin{array}{r}1785 \\
\pm 345 \\
<\end{array}$ & $\begin{array}{l}1182 \\
\pm 242 \\
.02\end{array}$ & $\begin{array}{r}37 \\
\pm 11<0\end{array}$ & $\begin{array}{r}\quad 66 \\
\pm 13 \\
01\end{array}$ \\
\hline
\end{tabular}

TSR, total systemic resistance; VCE, velocity of contractile elements $(\mathrm{dP} / \mathrm{dt} / \mathrm{P}) ; \mathrm{V}_{\max }, \mathrm{VCE}$ linearly extrapolated to $\mathrm{P}=0 \mathrm{mmHg}$; LVP, left ventricular pressure; ESP, pressure at aortic valve closure; TCR, time constant of relaxation; C, control; N, nifedipine. 


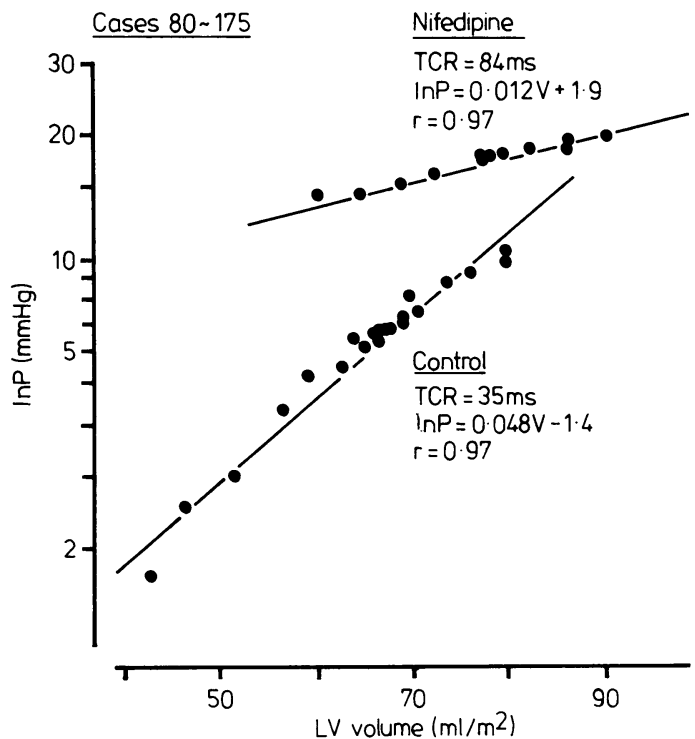

Fig. 4 Pressure-volume relation during diastole before and after nifedipine. Linear regression equation of the relation between the natural logarithm of left ventricular pressure $(\ln P)$ and left ventricular volume is shown. Intracoronary nifedipine results in a reduction in the slope $(k p)$ of the regression line. $T C R$, time constant of relaxation.

Fig. 5 Effect of nifedipine into the left main coronary artery on left ventricular anterior wall motion and its time sequence. Arrows indicate onset and the moment of maximal segmental wall displacement. Nifedipine induces a delay in onset of displacement, a decrease in the extent of segmental wall motion, and $a$ delay in the maximal wall displacement. (A) Control left ventriculogram. (B) Left ventriculogram after nifedipine. $E D$, end-diastole; $A V C$; aortic valve closure.

\section{A}
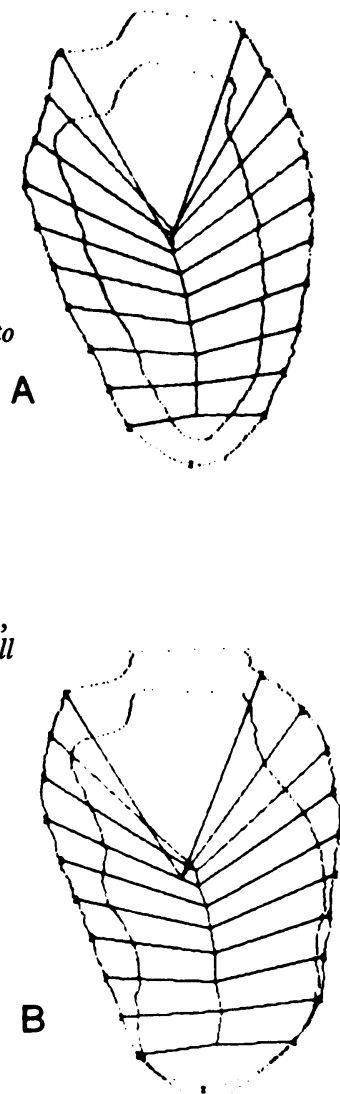

JPHD

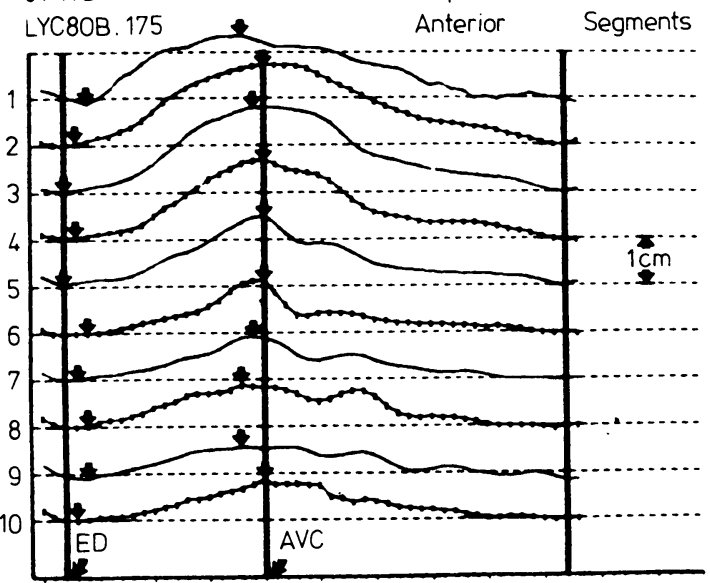

LYC80C 175

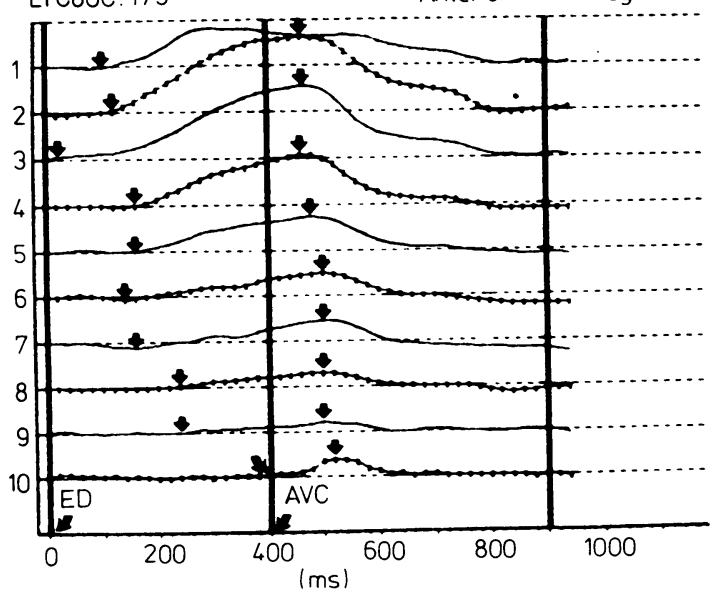


Table 2 Regional contractile and pump function and time relation

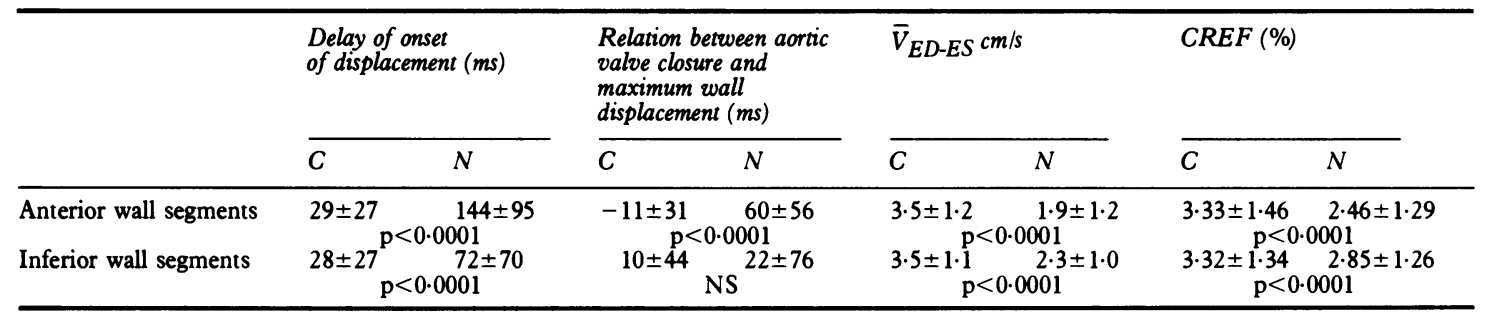

C, control values; $N$, values 30 seconds after nifedipine; $\overline{\mathrm{v}}$, mean velocity; ED, end-diastolic (based on pressure measurement); ES, end-systolic (based on pressure measurement); CREF, regional contribution to global ejection fraction. Values expressed as means $\pm S D ; p, p$ value Student's $t$ test (paired data).

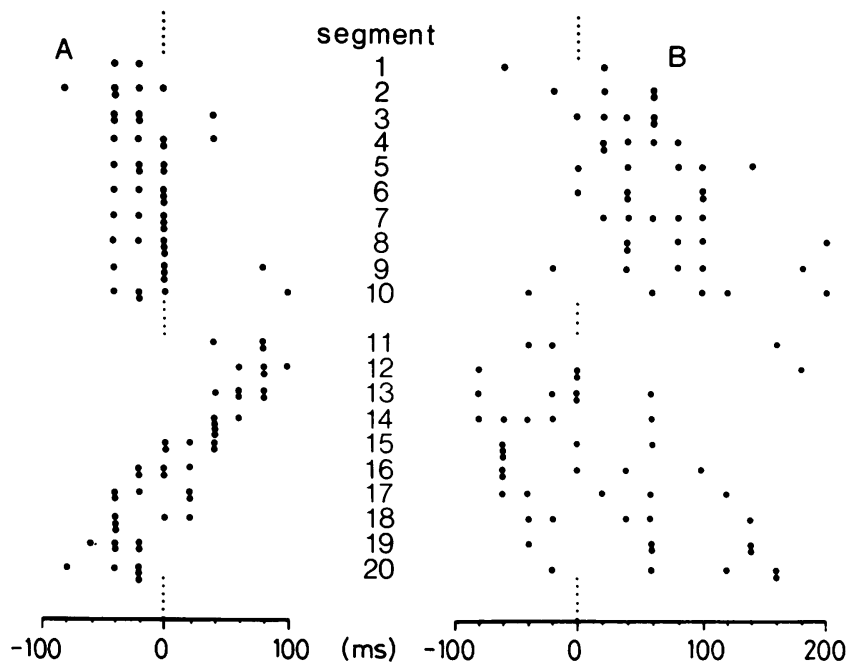

Fig. 6 Time relation between aortic valve closure (time zero) and the occurrence of maximal wall displacement before $(A)$ and after $(B)$ intracoronary nifedipine. In 13 of 200 segments the moment of maximal wall displacement could not be determined accurately. These data are omitted in the figure.

projector ${ }^{\star}$ and the selected frame converted into video format with a high resolution video camera for interactive computer processing. ${ }^{11}$ The contours of the arterial segment are detected automatically by means of an averaging first derivative function applied to the digitised video brightness levels. The final output of the system for a segment of the left anterior descending artery in the right anterior oblique projection is shown in Fig. 3. From the detected contour positions a diameter function is computed which is also shown in Fig. 3.

To determine the mean diameter of a part of the processed arterial segment the user must indicate the boundaries of the part in question. It is emphasised that the $x$-ray system settings were not changed during consecutive filming after drug injection. Calibra-

*Tage Arno tion of the diameter values in $\mathrm{mm}$ is, therefore, not necessary for comparative changes. The results after nifedipine administration are then expressed as relative changes in diameters, with respect to the control situation.

The accuracy and precision of the quantification method have been validated from cinefilms of copper models of obstructed coronary arteries with circular cross-sections suspended in $10 \mathrm{~cm}$ water. The accuracy was found to be $1.9 \%$ and the precision (variability) $1 \cdot 6 \%$.

\section{Results}

GLOBAL SYSTOLIC AND DIASTOLIC LEFT VENTRICULAR FUNCTION

Left ventricular pressure and volume measurements before and 30 seconds after intracoronary nifedipine 

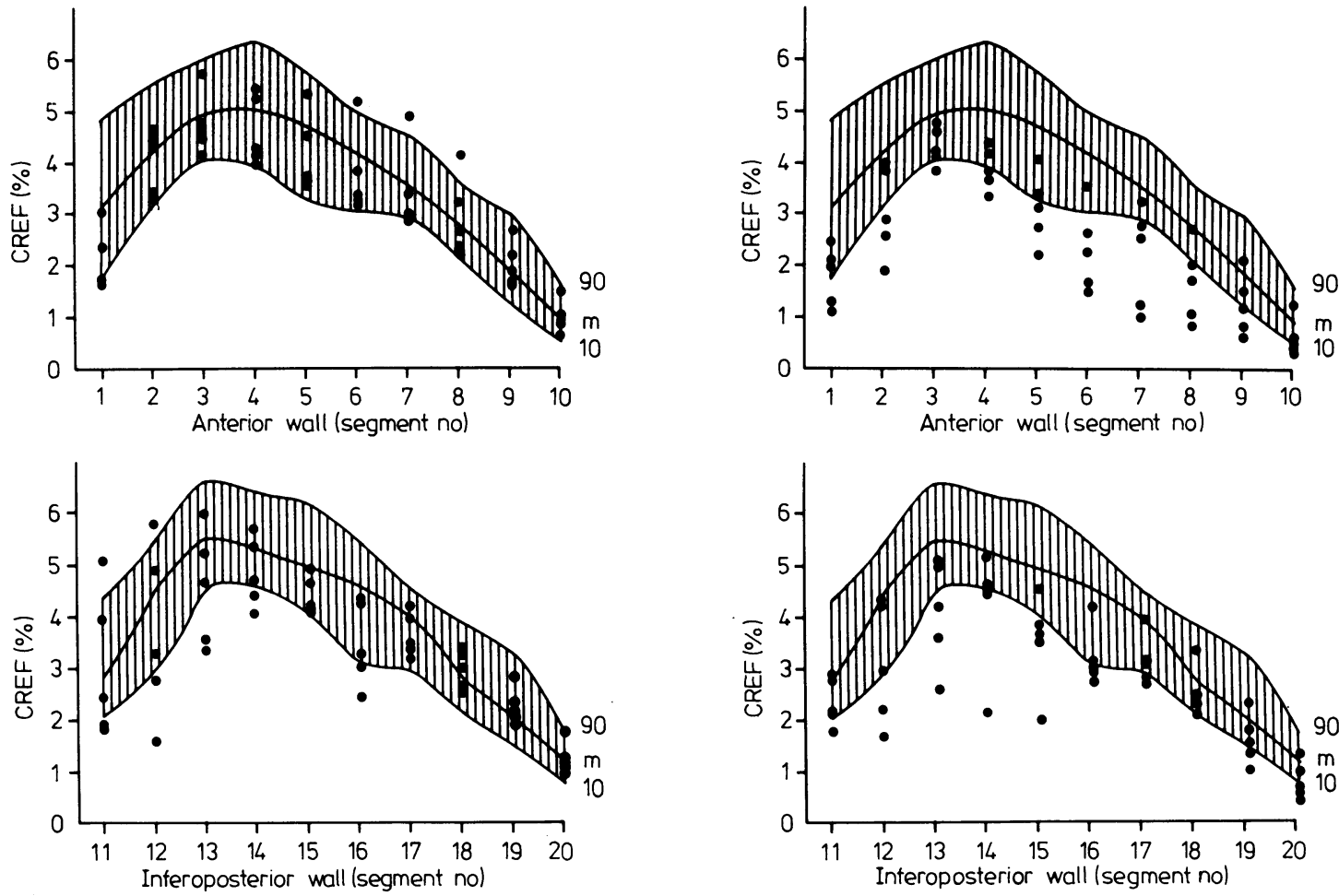

Fig. 7 Effect of nifedipine injection into the left main coronary artery on regional contribution to global ejection fraction (CREF). Left side of the Figure: individual CREF values (five patients) in the anterior and inferoposterior wall segments before nifedipine injection. Shaded areas represent the normal range of $C R E F$ values. Right side of the Figure: after nifedipine an overall depression of regional pump function is observed which is more pronounced in the anterior (segments $1-8)$ and apical $(9,10,19,20)$ areas.

are shown in Table 1a and $1 \mathrm{~b}$. The heart rates remained essentially unchanged, while peak systolic pressure, peak positive $\mathrm{dP} / \mathrm{dt}$, peak negative $\mathrm{dP} / \mathrm{dt}$, and peak $V_{C E}$ and $V_{\max }$ decreased significantly. In addition, the end-diastolic pressure became raised and the time constant of relaxation increased. Enddiastolic volumes did not change significantly, but there was an increase in the end-systolic volume, with a consistent decrease in stroke index and thus ejection fraction. Because of this decrease in cardiac output, and in spite of the transient reduction in blood pressure, the total systemic resistance remained unchanged. In four of five patients, the mean rate of flow, measured during the early diastolic filling period, between the mitral valve opening and the point of minimal pressure declined.

The relation between left ventricular diastolic pressure and volume after nifedipine is illustrated by one

Table 3 Effect of intracoronary nifedipine $(0.15 \mathrm{mg})$ on coronary sinus blood flow and myocardial oxygen consumption in 10 patients 20 coronary artery disease

\begin{tabular}{|c|c|c|c|c|c|c|c|c|c|c|}
\hline & \multicolumn{3}{|c|}{$H R / \min$} & \multicolumn{3}{|c|}{$\begin{array}{l}\text { Mean aortic pressure } \\
(\mathrm{mmHg})\end{array}$} & \multicolumn{3}{|c|}{$\begin{array}{l}\text { CSBF } \\
(\mathrm{ml} / \mathrm{min})\end{array}$} & ए \\
\hline & $C$ & $N 1$ & $N 2$ & $C$ & $N I$ & $N 2$ & $C$ & $N 1$ & $N 2$ & $\stackrel{c}{c}$ \\
\hline $\begin{array}{l}\text { Mean } \\
\text { SD } \\
\text { Cvs N1 } \\
\text { Cvs N2 } \\
\text { Cvs N2 }\end{array}$ & $\begin{array}{r}65 \\
\pm 8\end{array}$ & $\begin{array}{c}74 \\
\pm 8 \\
\mathrm{p}<0.002 \\
\mathrm{NS} \\
\mathrm{p}<0.0005\end{array}$ & $\begin{array}{r}65 \\
\pm 9\end{array}$ & $\begin{array}{r}111 \\
\pm 13\end{array}$ & $\begin{array}{c}98 \\
\pm 13 \\
\mathrm{p}<0.0005 \\
\mathrm{NS} \\
\mathrm{p}<0.0005\end{array}$ & $\begin{array}{r}112 \\
\pm 10\end{array}$ & $\begin{array}{r}103 \\
\pm 30\end{array}$ & $\begin{array}{c}155 \\
\pm 40 \\
\mathrm{p}<0.0005 \\
\mathrm{NS} \\
\mathrm{p}<0.001\end{array}$ & $\begin{array}{r}109 \\
\pm 36\end{array}$ & Oें \\
\hline
\end{tabular}

$\mathrm{C}$, control values; $\mathrm{N} 1$, values 30 seconds after nifedipine; $\mathrm{N} 2$, values 3 minutes after nifedipine; HR, heart rate; CSBF, coronary sinus blood flow; coronary vascular resistance; (Ao-Cs) $\mathrm{O}_{2}$, aortic/coronary sinus $\mathrm{O}_{2}$ difference; $\mathrm{MVO}_{2}$, myocardial oxygen consumption; $\mathrm{p}, \mathrm{p}$ value Student's test $\left(\mathrm{B}^{2}\right.$ data).

Values expressed as mean $\pm \mathrm{SD}$. 
example (Fig. 4). It is evident that the entire diastolic pressure-volume relation is shifted so that, at any given volume, pressure is higher. This effect was consistently seen after each administration of nifedipine. The slope of the $\mathrm{LnP}$ vs volume line, however, (K)-an index of volume stiffness-was considerably reduced in all patients.

\section{REGIONAL LEFT VENTRICULAR FUNCTION}

The profound effect of intracoronary nifedipine on left ventricular wall motion and its time sequence is shown in Fig. 5. Before administration of nifedipine, displacement of the anterior and inferior wall was seen, 29 and $28 \mathrm{~ms}$, respectively, after end-diastole (Table 2). After injection of nifedipine into the main stem of the left coronary artery, the onset of displacement of the anterior wall was delayed an additional $115 \mathrm{~ms}(\mathrm{p}<0.001)$, while the inferior wall was delayed by $44 \mathrm{~ms}(\mathrm{p}<0.001)$. For each segment the timing relation between aortic valve closure and the occurrence of the maximal wall displacement is shown in Fig. 6. Before nifedipine, the maximal displacement of the anterior wall occurred $11 \mathrm{~ms}$ before aortic valve closure. In contrast, with the anterior wall segments, the inferoposterior wall segments did not reach their maximal wall displacement synchronously. The maximal displacement of the five posterobasal segments (no. 11-15) occurred between 20 and $100 \mathrm{~ms}$ after aortic valve closure so that the maximal wall displacement of the entire inferior wall fell, on average, $10 \mathrm{~ms}$ after aortic valve closure. After nifedipine, the moment of maximal wall displacement for the anterior wall shifted from end-systole $(11 \mathrm{~ms}$ before aortic valve closure) to early diastole $(60 \mathrm{~ms}$ after aortic valve closure). The anterolateral and the apical segment of the anterior wall, as well as the apical segment of the inferior wall appear to be the most affected. On the contrary, the posterobasal wall segments reach their maximum in end-systole, instead of early diastole.

The measurement of mean systolic wall velocity after nifedipine showed a decrease which was again more pronounced in the anterior wall (Table 2) than in the inferior wall. The individual regional pump function data for all 20 segments before and after the intracoronary administration of nifedipine are given in Fig. 7. Though these data demonstrated a myocardial depression affecting the whole ventricle, the anterolateral and apical segments were most severely affected. Two patients with a dominant left coronary artery showed an impressive reduction of the pump function of their posterobasal wall segments as well. Under the influence of nifedipine, the mean values of regional contribution to global injection fraction decreased from 3.33 to $2.46 \%(p<0.0001)$ for the anterior wall and from 3.32 to $2.85 \%(p<0.0001)$ for the inferior wall.

\section{CORONARY SINUS BLOOD FLOW AND}

MYOCAR DIAL OXYGEN CONSUMPTION

Thirty seconds after intracoronary administration of nifedipine, coronary sinus blood flow increased significantly $(p<0.005)$ from $103 \mathrm{ml} / \mathrm{min}$ to $155 \mathrm{ml} /$ min but returned to the pre-administration values within three minutes (Table 3). Simultaneously, mean aortic blood pressure dropped from $111 \mathrm{mmHg}$ to 98 $\mathrm{mmHg}$ then returned to control values. Despite this transient decrease in perfusion pressure, coronary vascular resistance was significantly reduced $(1 \cdot 15$ versus $0.66 \mathrm{mmHg} / \mathrm{ml}$ per min; $p<0.0002$ ). Thirty seconds after nifedipine, the coronary sinus oxygen content almost doubled (from 6.0 to $11.9 \mathrm{ml} / 100 \mathrm{ml}$; $\mathrm{p}<0.0001$ ), and this was reflected in a considerable narrowing of the aortic-coronary sinus oxygen difference (from 12.7 to $6.3 \mathrm{ml} / 100 \mathrm{ml} ; \mathrm{p}<0.0001$ ). In this group of patients, the net increase in myocardial blood flow was smaller than expected from the narrowing of the aortic-coronary sinus oxygen difference, reflecting a reduced myocardial oxygen consumption (from 13.4 to $9.6 \mathrm{ml} / \mathrm{min} ; \mathrm{p}<0.01$ ).

\section{QUANTITATIVE CORONARY CINEANGIOGRAPHY}

Haemodynamic data assessing the effects of nifedipine on the epicardial coronary arteries are shown in Table 4. Peak systolic pressure remained constant during both control cineangiograms, but decreased by $14 \mathrm{mmHg}$ immediately after the intracoronary injection of nifedipine $(p<0.05)$. This acute change was transient so that by the time the

\begin{tabular}{|c|c|c|c|c|c|c|c|c|c|c|c|}
\hline \multicolumn{3}{|c|}{$\begin{array}{l}\text { CVR } \\
(m m H g / m l \text { per } \mathrm{min})\end{array}$} & \multicolumn{3}{|c|}{$\begin{array}{l}(A o-C s) \mathrm{O}_{2} \\
(\mathrm{ml} / 100 \mathrm{ml})^{2}\end{array}$} & \multicolumn{3}{|c|}{$\begin{array}{l}\mathrm{CS} \mathrm{O}_{2} \text { content } \\
(\mathrm{ml} / 100 \mathrm{ml})\end{array}$} & \multicolumn{3}{|c|}{$\begin{array}{l}\mathrm{MVO}_{2} \\
(\mathrm{ml} / \mathrm{min})\end{array}$} \\
\hline$C$ & $N 1$ & $N 2$ & $C$ & $N I$ & N2 & $C$ & $N I$ & N2 & $C$ & $N 1$ & $N 2$ \\
\hline $\begin{array}{r}1.15 \\
\pm 0.31\end{array}$ & $\begin{array}{c}\quad 0.66 \\
\pm 0.15 \\
p<0.0002 \\
N S \\
p<0.0005\end{array}$ & $\begin{array}{r}1.12 \\
\pm 0.35\end{array}$ & $\begin{array}{r}12.7 \\
\pm \quad 1.5\end{array}$ & $\begin{aligned} & 6.3 \\
& \pm 1.6 \\
& p<0.0001 \\
& p<0.005 \\
& p<0.0001\end{aligned}$ & $\begin{aligned} & 11.9 \\
\pm & 1 \cdot 1\end{aligned}$ & $\begin{array}{r}6.0 \\
\pm 1.1\end{array}$ & $\begin{array}{c}11.9 \\
\pm 1.4 \\
p<0.0001 \\
p<0.02 \\
p<0.0001\end{array}$ & $\begin{array}{r}6.6 \\
\pm 0.7\end{array}$ & $\begin{array}{r}13.4 \\
\pm \quad 4.9\end{array}$ & $\begin{array}{c}9.6 \\
\pm 3.1 \\
p<0.01 \\
N S \\
p<0.01\end{array}$ & $\begin{array}{r}13.7 \\
+\quad 6.1\end{array}$ \\
\hline
\end{tabular}


Table 4 Pressure derived variables and coronary sinus saturation during the two control $(C 1, C 2)$ and the two post-nifedipine cineangiograms $(N 1, N 2)$ (Mean \pm SEM)

\begin{tabular}{|c|c|c|c|c|c|c|}
\hline & $\begin{array}{l}\text { Peak LVSP } \\
\text { (mmHg) }\end{array}$ & $\begin{array}{l}\text { LVEDP } \\
\mathrm{mmHg}\end{array}$ & $V_{\max / s}$ & $\begin{array}{l}\text { Peak dP/dt } \\
(\mathrm{mmHg} / \mathrm{s})\end{array}$ & Peak VCE $/ \mathrm{s}$ & $\underset{\%}{C S_{02}}$ sat \\
\hline $\begin{array}{l}\mathrm{C} 1 \\
\mathrm{C} 2 \\
\mathrm{~N} 1 \\
\mathrm{~N} 2 \\
\mathrm{C} 1 \text { vs } \mathrm{N} 1 \\
\mathrm{C} 1 \text { vs } \mathrm{N} 2 \\
\mathrm{C} 2 \text { vs } \mathrm{N} 1 \\
\mathrm{C} 2 \text { vs } \mathrm{N} 2 \\
\mathrm{~N} 1 \text { vs } \mathrm{N} 2\end{array}$ & $\begin{array}{l}135 \pm 11.5 \\
137 \pm 11.6 \\
123 \pm 8.4 \\
135 \pm 11 \\
p<0.05 \\
\text { NS } \\
p<0.005 \\
\text { NS } \\
p<0.03\end{array}$ & $\begin{array}{l}18 \pm 2.6 \\
19 \pm 2.6 \\
25 \pm 3.1 \\
22 \pm 2.6 \\
\mathrm{p}<0.002 \\
\text { NS } \\
\text { p }<0.001 \\
\text { NS } \\
\text { NS }\end{array}$ & $\begin{array}{l}47.8 \pm 2.3 \\
45 \pm 2.10 \\
36.7 \pm 2.8 \\
47.5 \pm 1.9 \\
p<0.005 \\
\text { NS } \\
p<0.002 \\
\text { NS } \\
p<0.002\end{array}$ & $\begin{array}{l}1722 \pm 191 \\
1607 \pm 120 \\
1333 \pm 139 \\
1629 \pm 139 \\
\mathrm{p}<0.02 \\
\text { NS } \\
\mathrm{p}<0.05 \\
\text { NS } \\
\mathrm{p}<0.02\end{array}$ & $\begin{array}{l}35.5 \pm 3 \cdot 8 \\
32 \pm 2.5 \\
24 \cdot 3 \pm 2.4 \\
31 \cdot 3 \pm 2.6 \\
p<0.02 \\
\text { NS } \\
\text { p }<0.01 \\
\text { NS } \\
\text { p }<0.01\end{array}$ & $\begin{array}{l}36 \pm 3.0 \\
36 \quad \pm 3.2 \\
63 \pm 4.7 \\
35.3 \pm 1.1 \\
\mathrm{p}<0.01 \\
\mathrm{NS} \\
\mathrm{p}<0.005 \\
\mathrm{NS} \\
\mathrm{p}<0.005\end{array}$ \\
\hline
\end{tabular}

Abbreviations: Peak LVSP, peak left ventricle systolic pressure; LVEDP, left ventricle end-diastolic pressure; $V_{\text {max }}$, maximal velocity of contractile element; $\mathrm{dP} / \mathrm{dt}$, first derivative LV pressure; peak VCE, peak velocity of contractile element; $\mathrm{CS}_{02}$ sat, coronary sinus oxygen saturation; $p$, p value Student's t test (paired); NS, not significant.

fourth coronary angiogram was recorded, the left ventricular pressure had already returned to its control value of $135 \mathrm{mmHg}$. End-diastolic pressure showed a significant increase from 19 to $25 \mathrm{mmHg}(\mathrm{p}<0.001)$ 30 seconds after nifedipine had been administered. During the fourth cinefilm, the end-diastolic pressure was still slightly, but not significantly, raised. After the intracoronary injection of nifedipine, peak $\mathrm{dP} / \mathrm{dt}$ and $V_{\max }$ decreased simultaneously by 17 and $18 \%$ and both variables returned to their control values by the time of the fourth coronary cineangiogram. As for the coronary sinus saturation, 30 seconds after the intracoronary administration of nifedipine there was a pronounced increase from $36 \%$ to $63 \%$ occurring simultaneously with the drop in $\mathrm{V}_{\max }$. It must be emphasised that five minutes after the intracoronary injection of nifedipine, there remained no detectable effect of nifedipine on the coronary sinus $\mathrm{O}_{2}$ saturation or on contractility. The effects of nifedipine on the mean diameter of 10 normal, five prestenotic, and 16 poststenotic segments are given in Table 5 and shown in Fig. 8. One of the 17 poststenotic segments was excluded from the statistical analysis because it showed a paradoxical reduction of $60 \%$ in diameter after nifedipine. There is no significant difference in the mean diameter between the first and the second control cinefilm. After administration of nifedipine (film $\mathrm{N} 2$ ), all segments $(\mathrm{N}=29)$ showed an increase of $12 \%(\mathrm{p}<0.0001)$ in mean diameter, except for three coronary segments (one prestenotic, two poststenotic in series in the same artery).

These changes in detail were as follows. Thirty seconds after the intracoronary injection of nifedipine there was already a small, but significant vasodilatation (C1 vs $\mathrm{N} 1,6.2 \%, \mathrm{p}<0.02 ; \mathrm{C} 2$ vs $\mathrm{N} 1,7.9 \%$, $\mathrm{p}<0.05)$ of the normal coronary segments. Five minutes later, on the last film (N2), there was an additional increase in mean diameter so that an overall increase of $10.3 \%(p<0.002)$ in mean diameter was observed between $\mathrm{C} 1$ and $\mathrm{N} 2$ and a $12.0 \%$ increase $(p<0.001)$ between film C2 and N2. Similar changes were seen in the prestenotic coronary segments (Table 5).

Thirty seconds after nifedipine there was also a significant increase in the luminal diameter of the poststenotic segments $(\mathrm{Cl}$ vs N1, 8.3\%, $<<0.002$ and $\mathrm{C} 2$ vs $\mathrm{N} 1,9 \%, \mathrm{p}<0.001)$. This vasodilatation persisted and increased further: all 16 segments showed an increase in mean diameter with an average of $15.7 \%(\mathrm{p}<0.0001)$ between films $\mathrm{C} 1$ and N2 and an average increase of $16.4 \%(p<0.0001)$ between films $\mathrm{C} 2$ and N2. Seven of the eight stenotic areas also

Table 5 Effect of intracoronary nifedipine on mean diameter of normal, prestenotic, and poststenotic coronary segments; percentage diameter change is defined as: $(B-A) / A \times 100$

\begin{tabular}{|c|c|c|c|c|c|c|c|c|}
\hline & & & $\begin{array}{l}\text { Normal segment } \\
n=10\end{array}$ & & $\begin{array}{l}\text { Prestenotic segment } \\
n=5\end{array}$ & & $\begin{array}{l}\text { Poststenotic segment } \\
n=16\end{array}$ & \\
\hline$A$ & & $B$ & $\begin{array}{l}\bar{m} \pm S D \\
\%\end{array}$ & $p$ & $\begin{array}{l}\bar{m} \pm S D \\
\%\end{array}$ & $p$ & $\begin{array}{l}\bar{m} \pm S D \\
\%\end{array}$ & $p$ \\
\hline $\begin{array}{l}\mathrm{C} 1 \\
\mathrm{Cl} \\
\mathrm{Cl} \\
\mathrm{C} 2 \\
\mathrm{C} 2 \\
\mathrm{~N} 1\end{array}$ & $\begin{array}{l}\text { vs } \\
\text { vs } \\
\text { vs } \\
\text { vs } \\
\text { vs } \\
\text { vs }\end{array}$ & $\begin{array}{l}\mathrm{C} 2 \\
\text { N1 } \\
\text { N2 } \\
\text { N1 } \\
\text { N2 } \\
\text { N2 }\end{array}$ & $\begin{array}{l}-2 \pm 6 \\
+6 \pm 6 \\
+10 \pm 7 \\
+8 \pm 6 \\
+12 \pm 7 \\
+4 \pm 7\end{array}$ & $\begin{array}{l}\text { NS } \\
0.02 \\
0.002 \\
0.05 \\
0.001 \\
\text { NS }\end{array}$ & $\begin{array}{l}+1 \pm 4 \\
+6 \pm 4 \\
+10 \pm 10 \\
+5 \pm 4 \\
+9 \pm 10 \\
+4 \pm 10\end{array}$ & $\begin{array}{l}\text { NS } \\
0 \cdot 04 \\
\text { NS } \\
\text { NS } \\
\text { NS } \\
\text { NS }\end{array}$ & $\begin{array}{l}-1 \pm 7 \\
+8 \pm 10 \\
+16 \pm 11 \\
+9 \pm 10 \\
+16 \pm 11 \\
+8 \pm 11\end{array}$ & $\begin{array}{l}\text { NS } \\
<0.002 \\
<0.0001 \\
<0.001 \\
<0.0001 \\
<0.0005\end{array}$ \\
\hline
\end{tabular}

$\mathrm{p}, \mathrm{p}$ value, Student's t test (paired data). 

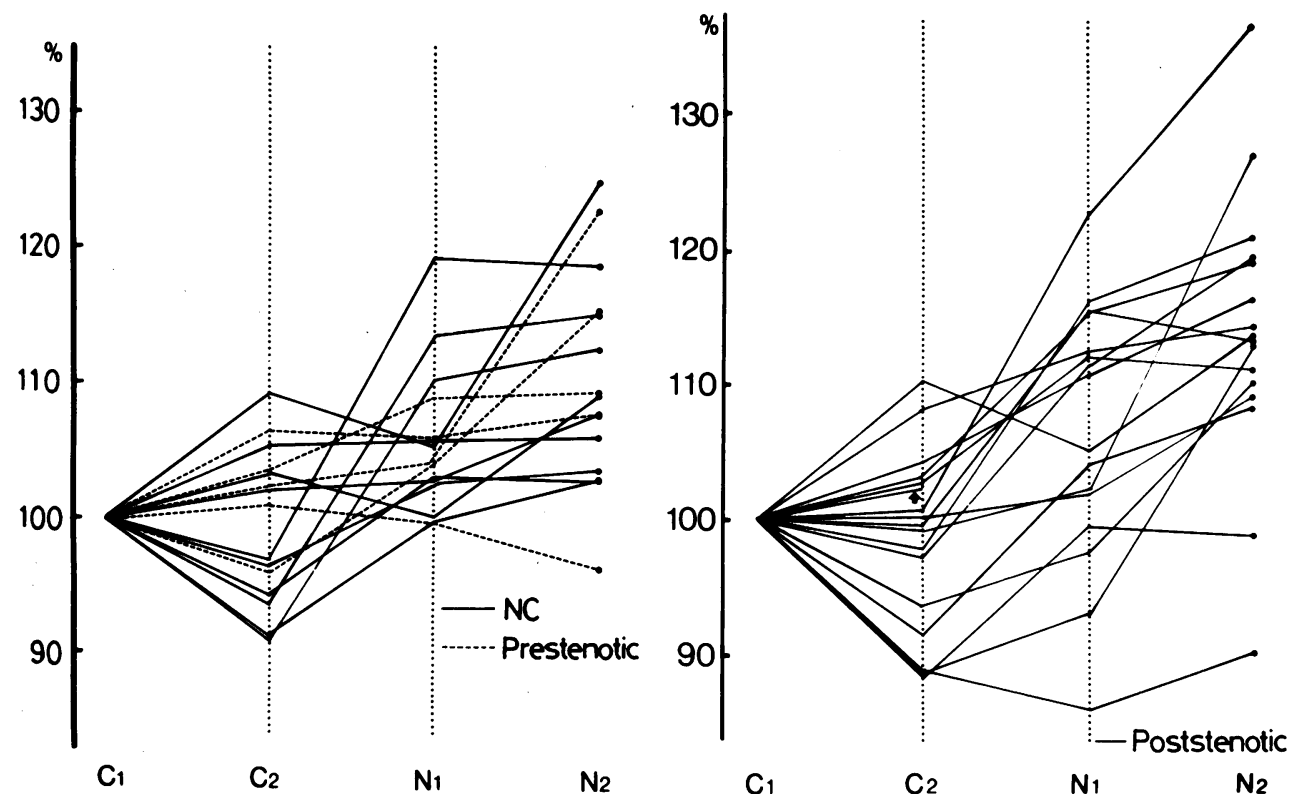

Fig. 8 Effect of intracoronary nifedipine on the mean diameter of 10 normal $(\dot{N} C)$, five prestenotic, 17 poststenotic coronary segments during two control cineangiograms $(C 1, C 2)$, and two cineangiograms after nifedipine (N1, N2). The individual diameter measurements are expressed as percentages with respect to $C l=100 \%$. Arrow indicates a segment which shows paradoxical reduction of $60 \%$ after nifedipine injection (see text).

dilated with nifedipine and their luminal diameters increased in absolute terms over a range of 4 to $30 \%$ (Table 6). There was a slight reduction in diameter in one segment.

It is clear that the normal, prestenotic, stenotic, and poststenotic segments remained in a state of vasodilatation even when $V_{\max }$ and the coronary sinus saturation had returned to their control values. In other words, nifedipine provokes a coronary vasodilatation which persists after the disappearance of its direct effects on the myocardium.

Table 6 Luminal diameters of eight stenotic lesions during control cineangiogram (C1) and after (N2) intracoronary administration of nifedipine; luminal diameters are expressed in pixels

\begin{tabular}{lcl}
\hline $\begin{array}{l}\text { Control } \\
\text { C1 }\end{array}$ & $\begin{array}{l}\text { Nifedipine } \\
\text { N2 }\end{array}$ & $\begin{array}{l}\text { Luminal diameter } \\
\text { change \% }\end{array}$ \\
\hline 4.73 & 6.18 & 31 \\
9.92 & 12.59 & 27 \\
10.93 & 13.67 & 25 \\
10.31 & 12.63 & 22.5 \\
13.75 & 16.10 & 17 \\
13.97 & 15.29 & 9.4 \\
8.32 & 8.68 & 4.3 \\
9.84 & 8.90 & -9.5 \\
\hline
\end{tabular}

Luminal diameter change is defined as: $(\mathrm{N}-\mathrm{C}) / \mathrm{C} \times 100$, and expressed as a percentage.

\section{Discussion}

\section{GLOBAL AND REGIONAL LEFT VENTRICULAR}

\section{FUNCTION}

Earlier studies of the direct effect of nifedipine on the myocardium were carried out in this laboratory in patients in whom radiopaque markers had been implanted on the epicardium at the time of bypass surgery. ${ }^{12}$

The question remained, however, to what extent regional endocardial movement was affected. In order to investigate this aspect, frame by frame analysis of the left ventricular cavity outline provided the opportunity to investigate the relation between changes in regional endocardial wall motion and alterations in left ventricular isovolumic contraction and relaxation, which have been described after intracoronary administration of nifedipine. ${ }^{13}$

Asynchrony in regional wall motion in itself could explain the disturbance in isovolumic contraction, the depressed systolic function, and the abnormalities in relaxation. ${ }^{1415}$ In other words, the teamwork which must exist between the different parts of a ventricle to provide maximal mechanical efficiency during ejection might be simply disrupted by the regional administration of nifedipine, without implying a true reduction in regional myocardial performance. It has 


\begin{tabular}{|c|c|c|c|c|c|}
\hline s & $D_{1}$ & $V_{1}$ & $\mathrm{D}_{2}$ & $\mathrm{VD}_{2}$ & $\Delta V D$ \\
\hline 1. & 1.40 & 2.29 & 1.40 & 2.29 & 0 \\
\hline 2. & 1.10 & 2.37 & 0.98 & 2.21 & -0.16 \\
\hline 3. & 1.12 & 2.62 & 1.20 & 2.73 & 0.11 \\
\hline 4. & 1.03 & 2.57 & 1.27 & 2.90 & 0.33 \\
\hline 5. & 0.83 & 2.17 & 1.17 & 2.65 & 0.48 \\
\hline 6. & 0.58 & 1.68 & 0.98 & 2.29 & 0.61 \\
\hline 7. & 0.55 & 1.54 & 0.74 & 1.85 & 0.31 \\
\hline 8. & 0.50 & 1.24 & 0.52 & 1.28 & 0.04 \\
\hline 9. & 0.40 & 0.82 & 0.33 & 0.74 & -0.08 \\
\hline 10. & 0.32 & 0.45 & 0.28 & 0.42 & -0.03 \\
\hline 11. & 1.60 & 2.48 & 1.00 & 1.88 & -0.60 \\
\hline 12. & 1.32 & 2.64 & 0.70 & 1.81 & -0.83 \\
\hline 13. & 0.95 & 2.37 & 0.40 & 1.45 & -0.92 \\
\hline 14. & 0.68 & 2.01 & 0.38 & 1.45 & -0.56 \\
\hline 15. & 0.50 & 1.60 & 0.52 & 1.64 & 0.04 \\
\hline 16. & 0.55 & 1.63 & 0.83 & 2.08 & 0.45 \\
\hline 17. & 0.52 & 1.49 & 0.68 & 1.75 & 0.26 \\
\hline 18. & 0.59 & 1.37 & 0.70 & 1.52 & 0.15 \\
\hline 19. & 0.55 & 1.00 & 0.73 & 1.18 & 0.18 \\
\hline \multirow[t]{2}{*}{20.} & 0.40 & 0.52 & 0.65 & 0.68 & 0.16 \\
\hline & & 34.86 & & 34.80 & \\
\hline
\end{tabular}

been suggested that the primary abnormality induced by intracoronary nifedipine could be a delayed onset of contraction without abnormal function. If this theory was correct, all disturbances described above could be the result of an electrophysiological delay in the activation of the Purkinje fibres, but recent work of Dangman and Hoffman ${ }^{16}$ showing that has all but excluded this possibility. It is more likely that the changes in isovolumic contraction and relaxation reflect either globally altered myocardial contractility or asynchrony of the electromechanical coupling within the sarcomere population. The data obtained from the analysis of endocardial wall motion favour the former hypothesis. A delay in the onset of wall displacement (Table 2) and a profound change in the timing relation between aortic valve closure and peak inward displacement of the individual wall segments were clearly shown. Normally, contraction ends in a synchronous manner, except for some physiological late contraction of the inferobasal area (Fig. 6). After nifedipine a considerable delay (Table 2 ) of the
Fig. 9 Segmental wall motion after intracoronary nifedipine during the isovolumic relaxation phase, between the closure of the aortic valve $(A V C)$ and the opening of the mitral valve $(M V O)$. See also Fig. 1. S: segment number; D1: segmental wall displacement ( $\mathrm{cm}$ ) between end-diastole $(E D)$ and AVC; D2: segmental wall displacement (cm) between ED and MVO; VDI: segmental volume displacement ( $\mathrm{ml}$ ) between $E D$ and $A V C$; VD2: segmental volume displacement (ml) between ED and MVO; $\triangle V D$ : changes in segmental volume between AVC and $M V O$, expressed in $\mathrm{ml}$.

anterior segments (4-8) and apical segments (8-10, 18-20) was seen, while contraction of the inferobasal segments (11-15) ended earlier. The mean velocity of systolic wall displacement $\left(\overline{\mathrm{V}}_{\mathrm{ED}-\mathrm{ES}}\right)$ was significantly reduced (Table 2). Furthermore, after intracoronary administration of nifedipine, regional contribution to ejection fraction of the anterior and inferior wall segments decreased, respectively, by 26 and $14 \%$.

Intracoronary nifedipine not only slows and depresses the segmental contraction, but also delays and prolongs it.

This latter observation led us to analyse another phenomenon. Since the volume of the ventricle is, by definition, constant during the relaxation perioddefined in terms of valve movement-inward movement in one area must be compensated for by outward movement elsewhere. This is illustrated and shown quantitatively in Fig. 9. Displacement $1\left(D_{1}\right)$ expresses for the individual segments the systolic inward wall displacement from end-diastole to aortic valve closure. Between aortic valve closure and mitral valve 
opening the majority of the anterior and inferoapical segments show a persisting inward wall motion, in contrast with the inferobasal segments which move outward. Column $\mathrm{D}_{2}$ (displacement 2) expresses the net effect of inward and outward wall displacement as computed just before mitral valve opening.

From the displacement $D_{1}$ and $D_{2}$ the segmental volume displacements are computed. The total volume displaced between end-diastole and aortic valve opening equals that displaced between end-diastole and mitral valve opening. Thus, the ventricular volume remains constant while a variety of segmental wall motion changes takes place. In studying this illustration it becomes obvious that changes in the rate of pressure relaxation may not only reflect a globally altered myocardial relaxation but also heterogeneity in activation and performance within the sarcomere population, with continuation of contraction and tension development extending into the isovolumic period. In other words, impaired relaxation of the ventricle as a whole must not automatically be equated with impaired relaxation at a cellular level.

Fleckenstein et al. ${ }^{17}$ have indicated that electromechanical decoupling occurs after nifedipine which leads to a decrease in actin-myosin interaction. The negative inotropic effect on the heart which was recorded and the upward shift in left ventricular diastolic pressure volume curves observed in this study are probably an expression of that fundamental biochemical effect: nifedipine interrupts the normal process by which calcium is transported to the cell, lowers the cytosolic calcium, and inhibits and delays contraction of the myocardial wall so that there is delay in diastolic interaction of contractile elements. This could be a reasonable explanation for the upward shift in left ventricular diastolic pressure volume curves. On the other hand, residual diastolic interaction between contractile elements-caused by an increased cytosolic calcium ${ }^{18}$ - has also been proposed as a possible explanation for the upward shift in diastolic pressure volume relations seen during angina. 1920

Cultures of dissociated beating ventricular cells from chick embryos manifested a negative inotropic response to calcium antagonism. ${ }^{21}$ That is, amplitude and velocity of contraction of the individual cells decreased in the presence of the drug, while there was no effect on velocity of cell wall motion during relaxation. Higher calcium concentrations, however, did cause a slowing in the rate of relaxation and a decrease in the amplitude of contraction as though the cells were in a constant state of partial contracture. Thus, the apparently conflicting observations are reconciled since the changes induced in cultured cells by high calcium concentrations are reversed by calcium antagonists, indicating "that calcium antagonist can dramatically improve systolic and diastolic function of a calcium-overloaded myocardial cell".

CORONARY BLOOD FLOW AND MYOCARDIAL OXYGEN CONSUMPTION

In our patients the myocardial oxygen consumption decreased by $28 \%$ after intracoronary injection of nifedipine. From our haemodynamic and angiographic data we assume that the decrease in myocardial oxygen consumption depended primarily on a decrease in contractility and left ventricular performance. This interpretation, however, is open to question, since despite an increase in global coronary blood flow, a decrease in endocardial flow and oxygen supply could make the endocardium ischaemic and consequently alter its mechanical performance. Others have pointed to the fact that after administration of a coronary vasodilator endocardial capillary blood flow may actually decrease because of an epicardial coronary "steal" phenomenon. ${ }^{22}$

This difference in regional blood flow response is seen particularly when coronary blood flow is increased in the presence of a critical stenosis of a large coronary artery. ${ }^{2324}$ In these circumstances, when flow is increased as a result of arteriolar dilatation distal to the stenosis, transmural perfusion becomes heterogeneous because of the greater increase in epicardial flow. ${ }^{25}$ In the present study we do not have any experimental evidence which would allow us to rule out this possibility, but Henry et al. ${ }^{26}$ have shown that, in dogs subjected to coronary occlusion, nifedipine increases collateral flow to the ischaemic myocardium. This increase was accompanied by a relative increase in endocardial perfusion, a phenomenon that was particularly prominent in the ischaemic zone. ${ }^{26}$

\section{QUANTITATIVE CORONARY ANGIOGRAPHY}

Although it has been proved that nifedipine dilates the coronary arteries, particularly in patients with variant angina, there have been few reports showing whether this drug actually dilates the coronary artery at the point of the stenotic lesions or at points distal to fixed obstructions. ${ }^{27}$

The present study provides quantitative measurements of the effects of nifedipine on the epicardial coronary artery after direct intracoronary administration. This route of administration was used in order to dissociate its coronary vasodilator action from its direct myocardial effect and afterload reduction. ${ }^{12} 28$ When nifedipine $(0.1 \mathrm{mg})$ was intravenously injected, it had no detectable haemodynamic effects. When nifedipine was regionally administered, it had a transient negative inotropic effect, associated with a transient increase in coronary blood flow and decrease in myocardial oxygen consumption. The vasodilatation of all three, the prestenotic, stenotic, and poststenotic 
coronary segments, persisted, however, much longer than the haemodynamic effects, at least during the period of observation in this study. This observation raises the possibility that there are distinct differences in the response to nifedipine between the myocardial cells and the smooth muscle cells in the coronary vascular wall.

Another essential question is: what effect do large vessel vasomotor tone and distal arteriolar resistance have on a proximal lesion? In isolated perfused human coronary arteries, a decrease in perfusion pressure can lead to a "dynamic" increase in resistance to flow across an elastic and eccentric stenosis. ${ }^{29}$

The study has even shown experimentally that the administration of a coronary vasodilator could induce a fall into distending pressure of the poststenotic coronary segment, resulting in a passive collapse of the wall of the stenotic segment and an increase in resistance to flow. ${ }^{30-32}$

An explanation for these conflicting possibilities may be that in the experimental studies the vasodilators affected primarily the distal arteriolar coronary bed leading to a reduction in poststenotic intraluminal pressure, whereas in the clinical studies the epicardial large coronary arteries were primarily affected in their prestenotic as well as in their poststenotic segment. ${ }^{33}$

\section{Conclusion}

Intracoronary nifedipine not only delays and prolongs the segmental contraction, but also slows and depresses it. It is suggested that a decreased cytosolic calcium might induce delayed diastolic interaction between contractile elements which could be a reasonable explanation for alteration of the isovolumic relaxation and for the upward shift in the left ventricular pressure volume curve after intracoronary administration of nifedipine. We presume that the decrease in myocardial oxygen consumption depends primarily on a decrease in contractility and left ventricular performance. Finally, we showed that the vasodilatation of the epicardial vessels after intracoronary nifedipine persists longer than its direct effects on the myocardium. In conclusion, the transient regional "cardioplegic" effect of nifedipine, associated with an increase in coronary blood flow, a reduction in $\mathrm{MVO}_{2}$, and a vasodilatation of the epicardial vessels, is likely to be beneficial during temporary coronary occlusion.

We acknowledge the technical assistance given by Johan C H Schuurbiers and Inge C J Zorn.

\section{References}

1 Hugenholtz PG, Michels HR, Serruys PW, Brower RW.
Nifedipine in the treatment of unstable angina, coronary spasm and myocardial ischemia. Am $\mathcal{F}$ Cardiol 1981; 47: 163-73.

2 Bertrand ME, Lablanche JM, Tilmant PY. Treatment of Prinzmetal's variant angina. Role of medical treatment with nifedipine and surgical coronary revascularization combined with plexectomy. Am f Cardiol 1981; 47: 174-8.

3 Serruys PW, van den Brand $M$, Brower RW, Hugenholtz PG. Regional cardioplegia and cardioprotection during transluminal angioplasty, which role for nifedipine? Eur Heart $\mathcal{F}$ (in press).

4 Serruys PW, van den Brand M, Hooghoudt TEH, et al. Coronary recanalization in acute myocardial infarction: immediate results and potential risks. Eur Heart $\mathcal{F} 1982$; 3: 404-15.

5 Meester GT, Bernard N, Zeelenberg C, Brower RW, Hugenholtz PG. A computer system for real time analysis of cardiac catheterization data. Cathet Cardiovasc Diagn 1975; 1: 113-32.

6 Fioretti P, Brower RW, Meester GT, Serruys PW. Interaction of left ventricular relaxation and filling during early diastole in human subjects. Am $\mathcal{F}$ Cardiol 1980; 46: 197-203.

7 Slager CJ, Hooghoudt TEH, Reiber JHC, Schuurbiers JCH, Booman F, Meester GT. Left ventricular contour segmentation from anatomical landmark trajectories and its application to wall motion analysis. Comput Cardiol 1979; 6: 347-50.

8 Gaasch WH, Levine HJ, Quinones MA, Alexander JK. Left ventricular compliance: mechanisms and clinical implications. Am $₹$ Cardiol 1976; 38: 645-53.

9 Ganz W, Tamura K, Marcus HS, Donoso R, Yoshido S, Swan HJC. Measurement of coronary sinus blood flow by continuous thermodilution in man. Circulation 1971; 44: 181-95.

10 Hugenholtz PG, Verdouw PD, Meester GT. Fiberoptics in cardiac catheterization II. Practical applications. In: Bloomfield DA, ed. Dye curves: the theory and practice of indicator dilution. Baltimore: University Park Press; Aylesbury: HM + M, 1974: 285-311.

11 Reiber JHC, Gerbrands JJ, Booman F, et al. Objective characterization of coronary obstructions from monoplane cineangiograms and three-dimensional reconstruction of an arterial segment from two orthogonal views. In: Schwartz MD, ed. Applications of computers in medicine. Long Beach, California: IEEE Computer Society, 1982: 93-100.

12 Serruys PW, Brower RW, ten Katen HJ, Bom AH, Hugenholtz PG. Regional wall motion from radiopaque markers after intravenous and intracoronary injections of nifedipine. Circulation 1981; 63: 584-91.

13 Rousseau MP, Veriter C, Detry JMR, Brasseur L, Pouleur H. Impaired early left ventricular relaxation in coronary artery disease: effects of intracoronary nifedipine. Circulation 1980; 62: 764-72.

14 Altieri PI, Wilt SM, Leighton RF. Left ventricular wall motion during the isovolumic relaxation period. Circulation 1973; 48: 499-505.

15 Gibson DG, Doran JH, Traill TA, Brown DJ. Regional abnormalities of left ventricular wall movement during isovolumic relaxation in patients with ischemic heart dis- 
ease. Eur f Cardiol 1978; 7, suppl: 251-64.

16 Dangman KH, Hoffman BF. Effects of nifedipine on electrical activity of cardiac cells. Am $\mathcal{F}$ Cardiol 1980; 46: 1059-67.

17 Fleckenstein vA, Tritthart H, Döring HJ, Byon KY. BAY a 1040-ein hochaktiver $\mathrm{Ca}^{++}$-antagonistischer Inhibitor der elektro-mechanischen Koppelungsprozesse im Warmblüter-Myokard. Arzneim Forsch 1972; 22: 22-3.

18 Lewis MJ, Grey AC, Henderson AH. Determinants of hypoxic contracture in isolated heart muscle preparations. Cardiovasc Res 1979; 13: 86-94.

19 Grossman W, Serizawa T, Carabello BA. Studies on the mechanism of altered left ventricular diastolic pressurevolume relations during ischaemia. Eur Heart f 1980; 1, suppl A: $141-7$.

20 Grossman W, Barry WH. Diastolic pressure-volume relations in the diseased heart. Fed Proc 1980; 39: 14855.

21 Lorell BH, Barry WH. Effects of verapamil on myocardial systolic and diastolic function during calcium overload (abstract). Circulation 1980; 62, suppl III: 293.

22 Lipscomb K, Gould KL. Mechanism of the effect of coronary artery stenosis on coronary flow in the dog. $\mathrm{Am}$ Heart f 1975; 89: 60-7.

23 Gould KL, Lipscomb K, Calvert C. Compensatory changes of the distal coronary vascular bed during progressive coronary constriction. Circulation 1975; 51: 1085-94.

24 Nakamura M, Matsuguchi H, Mitsutake A, et al. The effect of graded coronary stenosis on myocardial blood flow and left ventricular wall motion. Basic Res Cardiol 1977; 72: 479-91.

25 Weintraub WS, Hattori S, Agarwal J, Bodenheimer MM, Banka VS, Helfant RH. Variable effect of nifedipine on myocardial blood flow at three grades of coronary occlusion in the dog. Circ Res 1981; 48: 937-42.

26 Henry PD, Shuchleib R, Clark RE, Perez JE. Effect of nifedipine on myocardial ischemia: analysis of collateral flow, pulsatile heat and regional muscle shortening. $A m \mathcal{F}$ Cardiol 1979; 44: 817-24.

27 Schulz W, Kober G, Krauss G, Kaltenbach M. Influence of intracoronary and intravenous nifedipine on diameters of coronary vessels and stenoses. In: Rafflenbeul W, Lichtlen PR, Balcon R, eds. Unstable angina. Stuttgart, New York: Georg Thieme, 1981: 259-65.

28 Kaltenbach M, Schulz W, Kober G. Effects of nifedipine after intravenous and intracoronary administration. $A m \mathcal{F}$ Cardiol 1979; 44: 832-8.

29 Logan SE. On the fluid mechanics of human coronary artery stenosis. IEEE Trans Biomed Eng 1975; 22: 32734.

30 Walinsky P, Santamore WP, Wiener L, Brest AN. Dynamic changes in the hemodynamic severity of coronary artery stenosis in a canine model. Cardiovasc Res 1979; 13: 113-8.

31 Santamore WP, Walinsky P. Altered coronary flow responses to vasoactive drugs in the presence of coronary arterial stenosis in the dog. Am $\mathcal{F}$ Cardiol 1980; 45: 27685.

32 Schwartz JS, Carlyle PF, Cohn JN. Effect of dilation of the distal coronary bed on flow and resistance in severely stenotic coronary arteries in the dog. Am $\mathcal{F}$ Cardiol 1979; 43: 219-24.

33 Gould KL. Dynamic coronary stenosis. Am $\mathcal{F}$ Cardiol 1980; 45: 286-92.

Requests for reprints to Dr P W Serruys, Thoraxcenter, Erasmus University, PO Box 1738, 3000 DR Rotterdam, The Netherlands. 